\title{
Fifty Ways to Develop Professionally: What Language Educators Need to Succeed
}

\author{
Mary Shepard Wong \\ Azusa Pacific University, U.S.A.
}

\begin{abstract}
This paper discusses the importance and purposes of professional development in the lives of language educators in the Asian context and describes what teachers need to consider in designing a professional development plan. It provides a definition, rationale, and fifty professional development activities with references and resources found in the TESOL literature. Three steps are proposed in the formation of professional development plans: 1) determine one's strengths and weaknesses, 2) consider one's current stage of development and what one wants to accomplish, and 3 ) select long and short term goals and the resources needed to accomplish them. It is posited that continued development is the obligation of the professional language educator and that through reflection upon one's practice, awareness of opportunities, and a comprehensive plan, educators can obtain their professional development goals even with limited resources.
\end{abstract}

\section{Definition of Professional Development}

How does one become a professional educator? In order to answer this question, one must consider what it means to be "professional." To be considered a professional, one needs to possess the theoretical background, mentored experience, professional affiliations, and certifications to meet the standards of excellence in the chosen field. Nunan (1999) adds that professionals act as advocates for their field. Thus, professionals have the knowledge, skills, qualifications, connections, and accountability to engage in their professions as advocates. Those who are considered professional represent what is best in their fields and are endorsed and respected by colleagues.

Given this description of professional, it is reasonable to expect that becoming a professional educator does not end with one's pre-service or even in-service education. Professional development is a lifelong endeavor, a way of being, and a perspective on how one practices as well the practice itself. It is possible to never become professional, or to lose one's professionalism. Some refer to this process in education as teacher development, and note that sustained learning is key. As Lange (1990) states, "Teacher development is a term used in the literature to describe a process of continual intellectual, experiential, and attitudinal growth of teachers ... [ [lt permits] continued growth both before and throughout a career . . . in which teachers continue to evolve in the use, adaptation, and application of their art and craft" ( $p$. 250). 


\section{Reasons to Engage in Professional Development}

Teachers are busy people, so the first question to address is why divert precious time and resources to ongoing development? Six reasons to engage in professional development are provided below, along with corresponding professional activities, related resources, and references. For an up-to-date, comprehensive list of over 70 papers related to professional development of language educators, see TIRF's (The International Research Foundation for English Language Education) Professional Development of Language Teachers: Selected References (2011), available online. For examples in the context of Laos and Thailand, see Fowle \& Durham (2001).

Raise awareness of strengths and weaknesses. When teachers cannot articulate their strengths as language educators, they miss opportunities to build upon their strong points to make an even greater impact. Likewise, teachers who are unaware of weaknesses in their teaching are not able to know what to change because they are not sure what is hindering their effectiveness. Awareness, or being cognizant of one's decisions and one's strengths and weaknesses in teaching, is key to teacher growth and development. Several professional development activities in the literature, therefore, deal directly with heightening one's awareness and helping one to reflect critically upon one's teaching in order to make changes and improve. See Table 1 for activities and related resources.

Most of these activities could be accomplished with little or no cost, such as keeping a journal, learning a language, peer observations, engaging in team teaching, finding a mentor, or conducting a survey. While compiling a portfolio, recording one's teaching, and engaging in action research may require extra resources and / or expertise, the other activities require only initiative, time, and discipline. 
Table 1

Professional Development to Raise Awareness of One's Strengths and Weaknesses

\begin{tabular}{|c|c|}
\hline Professional Development Activity & Related Resources and References \\
\hline 1. Keep a journal and reflect on teaching & $\begin{array}{ll}\text { - } & \text { Bailey, } 2004 \\
\text { - } & \text { Bailey, Curtis, \& Nunan, 2001, Ch. } 4 \\
\text { - } & \text { Bailey \& Nunan, } 1996 \\
\text { - } & \text { Johnson \& Golombek, } 2002 \\
\text { - } & \text { Stewart \& Lokon, } 2003\end{array}$ \\
\hline 2. Learn a new language & $\begin{array}{ll}\text { - } & \text { Bailey, Curtis, \& Nunan, 2001, Ch. } 6 \\
\text { - } & \text { Rubin \& Thompson, } 1994 \\
\text { - } & \text { Sauro, } 2003\end{array}$ \\
\hline 3. Record and view one's teaching & $\begin{array}{ll}\text { - } & \text { Bailey, Curtis, \& Nunan, 2001, Ch. } 7 \\
\text { - } & \text { Richards \& Farrell, 2005, Ch. } 3\end{array}$ \\
\hline 4. Be observed by a peer & $\begin{array}{l}\text { - } \quad \text { Bain, } 2004 \\
\text { - } \quad \text { Richards, } 1998\end{array}$ \\
\hline 5. Observe other teachers & $\begin{array}{ll}\text { - } & \text { Deacon, } 2003 \\
\text { - } & \text { Wajnryb, } 1992\end{array}$ \\
\hline 6. Compile a portfolio & $\begin{array}{ll}\text { - } & \text { Bailey, Curtis, \& Nunan, 2001, Ch. } 12 \\
\text { - } & \text { Diaz-Maggioli, } 2003 \\
\text { - } & \text { Richards \& Farrell, 2005, Ch. } 7 \\
\text { - } & \text { Tanner, } 2003\end{array}$ \\
\hline 7. Engage in team teaching & $\begin{array}{l}\text { - } \quad \text { Bailey, Curtis, \& Nunan, 2001, Ch. } 10 \\
\text { - } \quad \text { Richards \& Farrell, 2005, Ch. } 11\end{array}$ \\
\hline 8. Find a mentor & $\begin{array}{l}\text { - } \quad \text { Bailey, Curtis, \& Nunan, 2001, Ch. } 11 \\
\text { - } \quad \text { Richards \& Farrell, 2005, Ch. } 10\end{array}$ \\
\hline 9. Engage in action research & $\begin{array}{ll}\text { - } & \text { Bailey, Curtis, \& Nunan, 2001, Ch. } 8 \\
\text { - } & \text { Burns, 1999, } 2010 \\
\text { - } & \text { Edge, } 2001 \\
\text { - } & \text { Freeman, } 1998 \\
\text { - } & \text { Richards \& Farrell, 2005, Ch. } 12\end{array}$ \\
\hline 10. Survey students on one's teaching & - Gordon, 2003 \\
\hline
\end{tabular}

Note. Many of the activities listed in Tables 1-6 could be listed under multiple reasons to engage in professional development, but are listed only once for ease of reference.

Acquire new knowledge. Another reason to engage in teacher or professional development is to acquire new knowledge. In the TESOL Quarterly 40 ${ }^{\text {th }}$ Anniversary Issue, Canagarajah (2006) mentions several areas within TESOL that are new to the field, such as World Englishes (WE), digital communication, and critical pedagogy. These are examples of how the field of TESOL has changed, and professional educators need to keep abreast of these changes. See Table 2 for a list of activities to gain new knowledge and their related resources. Although activities such as attending a conference or enrolling in an advanced degree program may require financial resources, many of the others can be completed with no funding. For example, some professional journals are available online. Reviewing, writing, or editing a book requires some 
previous knowledge and expertise, but one can collaborate with more experienced educators and learn from them in the process.

The possibility of attending conferences or getting an advanced degree should not be ruled out if funding is the only obstacle. Many conferences offer competitive travel awards which are often reserved for presenters from developing countries (see http://www.tesol.org/s_tesol/ seccss.asp?CID=362\&DID=1979), and there are also scholarships available for degree programs. In addition, choice of universities should not be limited to those in the West. Attending university in countries in Asia is more affordable and would likely be more appropriate for those who plan to teach in Asia.

\section{Table 2}

Professional Development to Acquire New Knowledge

\begin{tabular}{|c|c|}
\hline Professional Development Activity & Related Resources and References \\
\hline 11. Attend a conference & $\begin{array}{l}\text { - AsiaTEFL, CamTESOL, ETA-ROC, JACET, } \\
\text { JALT, KATE, KOTESOL, TEFLIN, TESOL, } \\
\text { ThaiTESOL }\end{array}$ \\
\hline 12. Read professional journals & $\begin{array}{l}\text { For a list of ELT journals, see pages 3-45 } \\
\text { of this document: } \\
\text { http://www.tesol.org/s_tesol/bin.asp?CID } \\
=334 \& D I D=1026 \& D O C=F I L E . P D F\end{array}$ \\
\hline 13. Become active in organizations & $\begin{array}{l}\text { - } \quad \text { Braine, } 2003 \\
\text { - } \quad \text { Eisterhold, } 2003\end{array}$ \\
\hline 14. Write a book review & - Kupetz, 2003 \\
\hline 15. Write a textbook manual or textbook & $\begin{array}{l}\text { - } \text { Grant, } 2003 \\
\text { - } \quad \text { Tjandrawidjaja, } 2003\end{array}$ \\
\hline 16. Become a reviewer of textbooks & $\begin{array}{l}\text { - See publishers' websites for more } \\
\text { information }\end{array}$ \\
\hline 17. Enroll in an MA or PhD program & $\begin{array}{ll}\text { - } & \text { Miller, } 2003 \\
\text { - } & \text { http://www.tesol.org/s_tesol/seccss.asp?C } \\
& \mathrm{ID}=1770 \& D I D=9326\end{array}$ \\
\hline 18. Launch a teachers' reading group & $\begin{array}{l}\text { - } \text { Sato, } 2003 \\
\text { - } \text { Richards \& Farrell, 2005, Ch. } 6\end{array}$ \\
\hline $\begin{array}{l}\text { 19. Teach a different level or course, or in a } \\
\text { different context }\end{array}$ & - Conrad, 2003 \\
\hline
\end{tabular}

Solve a particular problem. Perhaps there is a particular problem to solve, such as how to take advantage of the different levels of English proficiency in one's classroom or how to address the use of L1 in the classroom. Professional development activities that may help target a particular issue are listed below with related resources in Table 3. Once again, many of these, such as engaging in a case study, interviewing colleagues, analyzing a critical incident, joining an online discussion list, or finding online resources, can be completed with few resources. 
Table 3

Professional Development to Solve a Particular Problem

\begin{tabular}{|l|l|}
\hline \multicolumn{1}{|c|}{ Professional Development Activity } & \multicolumn{1}{c|}{ Related Resources and References } \\
\hline 20. Engage in a case study & $\begin{array}{l}\text { - Bailey, Curtis, \& Nunan, 2001, Ch. } 5 \\
\text { - Richards \& Farrell, 2005, Ch. } 9\end{array}$ \\
\hline 21. Interview colleagues & - Gorsuch \& Beglar, 2003 \\
\hline 22. Present at a conference & - Andrade, 2003 \\
\hline 23. Analyze a critical incident & - Borg, 2003b \\
& - Richards \& Farrell, 2005, Ch. 8 \\
\hline 24. Conduct an online survey & - See www.surveymonkey.com \\
\hline 25. Join an online discussion list & - Algren, 2003 \\
\hline 26. Find related online resources & - Chao, 2003 \\
& - Paulus, 2003 \\
\hline 27. Start a special interest group & - Braine, 2003 \\
\hline
\end{tabular}

Upgrade skills due to changes in society or the field. Ongoing in-service training and retooling is necessary for a professional language educator due to changes in both society and the field of language learning and education. This is perhaps most evident in the use of technology in the classroom. Knowing how to use these tools may require additional training, but much can be learned on one's own by going online. Professional development activities that lend themselves to practical hands-on retooling are listed below with related resources. Many of these require funding, but finding ways to learn from colleagues or perhaps offering help to others to upgrade their skills should not be overlooked.

Table 4

Professional Development to Upgrade Skills

\begin{tabular}{|c|c|}
\hline Professional Development Activity & Related Resources and References \\
\hline 28. Attend a workshop in desired area & - $\quad$ Richards \& Farrell, 2005, Ch. 2 \\
\hline 29. Find ways to learn from colleagues & $\begin{array}{l}\text { - Murphey, Connolly, Churchill, } \\
\text { McLaughlin, Schwartz, \& Krajka, } 2003\end{array}$ \\
\hline 30. Apply for a grant to learn a skill & $\begin{array}{ll}\text { - } & \text { Averill, } 2003 \\
\text { - } & \text { Seymour, } 2003\end{array}$ \\
\hline 31. Take an online or distance course & $\begin{array}{ll}\text { - } & \text { Green, } 2003 \\
\text { - } & \text { Pawan \& Jacobson, } 2003 \\
\text { - } & \text { Roessingh \& Johnson, } 2005\end{array}$ \\
\hline
\end{tabular}

Advance one's career. Professional development that is initiated by teachers and not just the institution has a better chance to succeed. The desire to get a promotion, tenure, or raise, or find a more challenging assignment can be a strong source of motivation. Professional activities that hold potential for advancing one's career are below in Table 5. Most of these, such as writing journal articles, co-writing a book, or creating a language program or school require some level of expertise or skills, but the simple act of volunteering in a professional 
organization or helping to produce a newsletter or publication can help one learn from others in the field at no cost.

\section{Table 5}

Professional Development to Advance One's Career

\begin{tabular}{|c|c|}
\hline Professional Development Activity & Related Resources and References \\
\hline 32. Get an advanced degree & - Miller, 2003 \\
\hline 33. Engage in and write up research & $\begin{array}{ll}\text { - } & \text { Borg, 2003a } \\
\text { - } & \text { Cohen, } 2003 \\
\text { - } & \text { McKay, } 2006\end{array}$ \\
\hline 34. Write a chapter or journal article & - Mattix, 2003 \\
\hline 35. Co-write or edit a book & - $\quad$ Murphy, 2003 \\
\hline 36. Apply for administrative positions & $\begin{array}{l}\text { - } \quad \text { Smith, } 2003 \\
\text { - } \quad \text { Stapa, } 2003\end{array}$ \\
\hline 37. Seek out positions as a teacher trainer & $\begin{array}{l}\text { - } \text { Bailey, } 2006 \\
\text { - } \text { Carbery \& Croker, } 2003\end{array}$ \\
\hline 38. Develop a language course & - Graves, 1996, 2000 \\
\hline 39. Create a language program & - $\quad$ Richards, 2001 \\
\hline 40. Establish a language school & - $\quad$ Richards, 2001 \\
\hline 41. Volunteer to serve & $\begin{array}{l}\text { - } \quad \text { Braine, } 2003 \\
\text { - } \quad \text { Eisterhold, } 2003\end{array}$ \\
\hline
\end{tabular}

Find fulfillment in one's work to prevent burnout. Promotions and advancement are not the only motivating factors to develop professionally. Finding fulfillment in one's work and preventing burnout are also good reasons to seek to grow in one's profession. Activities that respond best to this orientation include many of those already mentioned as well those listed in Table 6. A sabbatical may not be possible for most educators unless they are at a well-funded university; if that is the case, other options on this list, such as mentoring others, organizing a conference, or teaching less advantaged students, can be considered. Curtis $(2006,2008)$ notes that collaborative professional development has a better chance to succeed than individual efforts. Relationships formed though volunteer service at professional organizations are invaluable, as noted by many leaders in the TESOL, Inc. organization (see Christison \& Murray, 2009). 
Table 6

Professional Development to Find Fulfillment and Prevent Burnout

\begin{tabular}{|c|c|}
\hline Professional Development Activity & Related Resources and References \\
\hline 42. Take a sabbatical & - $\quad$ Seymour, 2003 \\
\hline 43. Start a student scholarship fund & $\begin{array}{l}\text { - http://us.scholargrants.info/how-do-you- } \\
\text { start-a-scholarship-fund }\end{array}$ \\
\hline 44. Organize a local conference & - Eisterhold, 2003 \\
\hline 45. Volunteer in an organization & - $\quad$ Braine, 2003 \\
\hline 46. Engage in international collaboration & - Carbery \& Croker, 2003 \\
\hline 47. Mentor other teachers & $\begin{array}{l}\text { - Waldschmidt, Dantas-Whitney, \& } \\
\text { Healey, } 2005\end{array}$ \\
\hline 48. Teach less advantaged students & - $\quad$ Boucher-Yip, 2003 \\
\hline 49. Start an ELT organization & - $\quad$ Braine, 2003 \\
\hline 50. Be an advocate for students & $\begin{array}{l}\text { - http://www.tesol.org/s_tesol/seccss.asp? } \\
\text { CID=32\&DID=37 }\end{array}$ \\
\hline
\end{tabular}

\section{Steps of Designing a Professional Development Plan}

The three steps in designing a professional development plan are to determine one's strengths and weaknesses, consider one's current stage of development, and select one's long-term and short-term goals.

Determine one's strengths and weaknesses. A helpful way to determine what to focus on in one's professional development plan is to consider three areas, or domains, in which one can develop: knowledge, attitude / awareness, and skills. This can be thought of one's head, heart, and hands. Since there are many possibilities under each domain to consider, language educators may want to choose one particular area of strength to build upon as well as one particular area of weakness to develop, and focus their plans around those two.

Head: General knowledge of teaching and specific subject matter knowledge. In terms of knowledge or the cognitive domain, there are two types of knowledge to consider developing. The first is general knowledge of teaching, such as knowing about various theories of learning and current research in education and its implications. The other area of knowledge that language educators need to consider is what they know about the specific content areas that they teach, whether it is grammar, pronunciation, writing, or culture.

Heart: Attitude / self-awareness. Attitude is key for the successful completion and sustaining power of any professional development plan. The literature on autonomy in language learning can be applied to teacher professional development. Essential elements in learner autonomy are motivation, choice, and responsibility. Teachers must consider how they can stay motivated to develop, be aware that they have choices about what and how they develop, and think about how they can be held responsible for their professional development plans. For example, teachers might seek out travel grants (which can help with their motivation) to present papers at conferences (on topics of their choice), and then share what they have learned with local colleagues upon their return (thus taking responsibility). 
In terms of self-awareness, educators who cannot articulate their strengths and weaknesses could focus their professional development plans on raising awareness of their teaching. A helpful tool to consider "blind spots" in one's teaching is the Johari Window (see Table 7). One's "open self" reveals aspects known to oneself and known by others. The fact that a teacher may teach in a nonlinear style may be evident to others as well as to the teacher herself, for example. The "secret self" is that which a person knows, but others are unaware of. For example, a teacher may feel insecure about teaching, although it may appear he has adequate confidence; this is known to the self, but hidden from others.

\section{Table 7}

Johari Window of the Four "Selves"

Known to self: $\quad$ Unknown to self:

\begin{tabular}{l|c|c|}
\hline Known to others: & OPEN SELF & BLIND SELF \\
Unknown to others: & SECRET SELF & HIDDEN SELF \\
\hline
\end{tabular}

The "blind self" has the most potential for growth. It is what others see, but which the individual is ignorant of. For example, a teacher may assume that his instructions in class are clear, but students may actually find them confusing. Or a teacher may think he is open to hearing students' comments and eager to listen to their questions, but his tone and nonverbal signals are sending unwelcome messages. Getting feedback from students, peers, and supervisors about what one does in the classroom and how one is perceived will reveal aspects of one's "blind self."

The bottom right window contains the "hidden self" which is concealed from others and oneself. It may be the hidden potential one has as a speaker, writer, motivator, or mentor, for example, just waiting to be discovered. Being willing to take some risks and try new things may open one's eyes to the hidden potential one has as a professional language educator.

Hands: Skills such as language proficiency and pedagogical expertise. Skills is another area one may wish to develop. Some teachers may feel they need to improve their English pronunciation if students find their spoken language difficult to follow, while other teachers may need to improve their skills in using software or technology. Improving one's teaching skills, whether it is designing better assessment instruments or becoming more skilled at providing specific feedback to students, is part of being a professional. However, the question is, which areas are one's greatest needs and which strengths should be developed?

Table 8 provides a space to write down a domain (Head, Heart, or Hand), a strength, a weakness, and corresponding professional development activities that support them. Examples have been provided. 


\section{Table 8}

Strengths, Weaknesses, and Related Activities

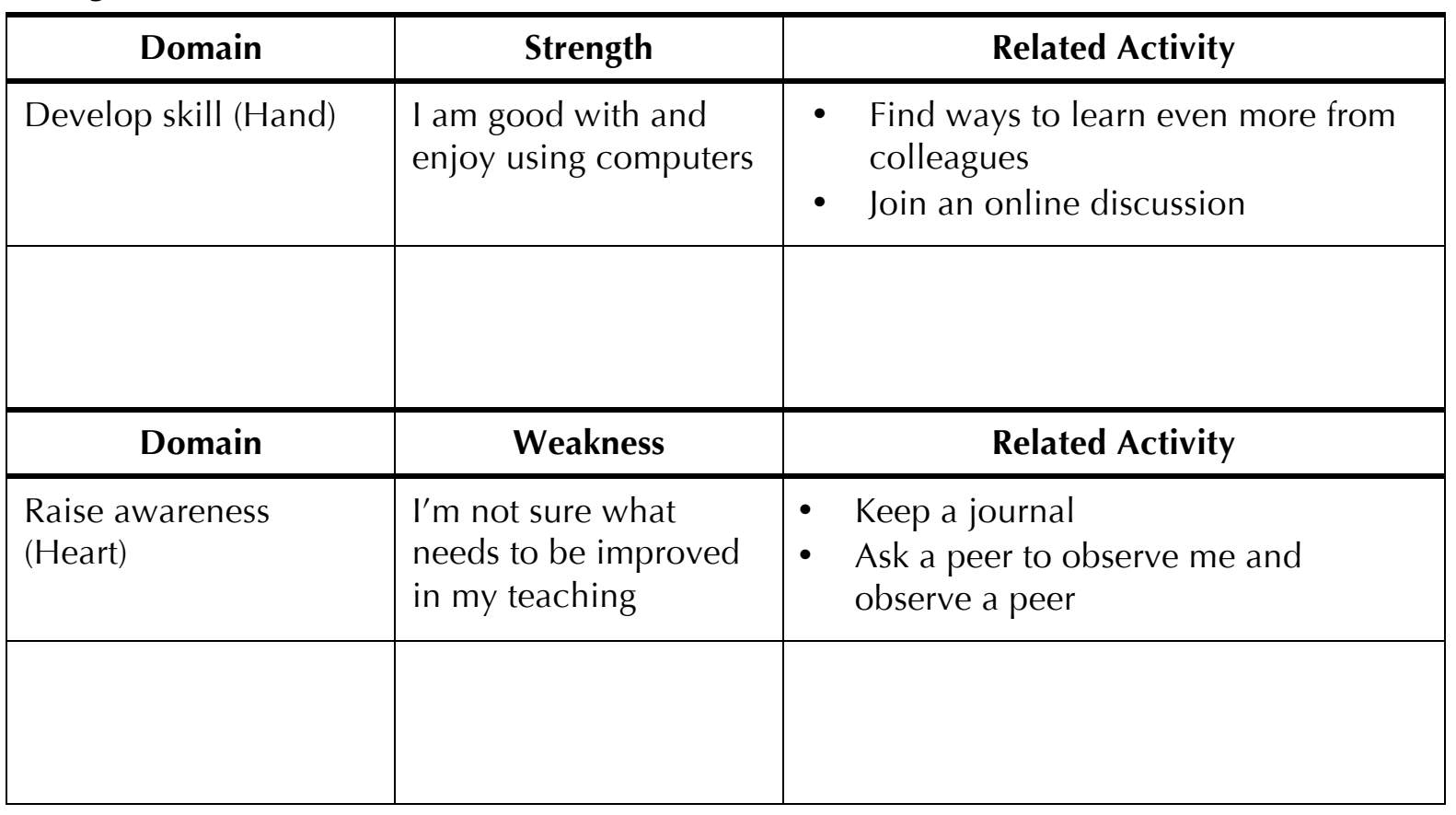

Consider one's current stage of development. Before determining where to go, one must take stock of where one is. Questions to consider are: What is lacking in one's education or experience to move forward? What is needed in order to be regarded as a professional educator? A useful tool to determine the answer to these questions is a curriculum vitae, or CV. Samples of CVs can be found online. A CV contains a list of evidence that documents one's professional accomplishments and activities. Most CVs contain the following categories: formal education, teaching experience, presentations, publications, professional memberships, leadership positions in professional organizations, and professional services. Sharing one's CV with colleagues and asking for suggestions in terms of what to add or delete can be useful. One can also look for "gaps" or items not present that a potential employer may be looking for or items needed for an ideal position, and use this knowledge to create a professional development plan.

Surveys have shown that novice teachers are often more concerned with the "what and how" questions, such "What do I teach on Monday?" and "How do I get quiet students to participate more?" while more experienced teachers ask the bigger questions of "so what" and "why" (see Richards \& Lockhart, 1996). More experienced teachers might ask, "Why teach this way, and what difference will this course make to this student in the future?" Asking the big questions is important when considering who one wants to become as an educator. An important outcome of teacher or professional development is a renewed vision of the world and one's place in it. While it is impossible to produce final solutions to world problems, it is important to envision the world one hopes to create and consider what type of person is needed to sustain such a world. As educators, the task is to consider what type of learning experiences will help prepare students who will fashion such a world.

It is this vision and the process of re-envisioning that will help both faculty and students find hope when faced with the complexities and harsh realities of a world that is marked by glaring injustices and inequality. This process becomes both a starting and ending point of learning 
and development, for it encompasses that which impels one to start the journey (the vision), sustains one in it (hope), and can produce evidence of change once through it (responsibility and respect). Palmer's (2007) book, The Courage to Teach, is one that thousands of teachers have found to be useful in rekindling a passion for teaching, students, and the subject that one teaches. Palmer speaks about teaching who one is and exploring one's inner-self, finding an integrity which can sustain teachers. Thus, questions of not only where one is, but who one is, why one is teaching, and who benefits from it can be compelling inquires that help one chart a course in professional development.

Select long-term and short-term goals. One's strengths and weaknesses, one's journey thus far, who one wants to become, and one's professional aspirations should be kept in mind when filling in Table 9 below. A long-term goal (7-10 years), three supporting short-term goals (2-5 years) that will help accomplish the long-term goal, the resources, obstacles, potential solutions, and deadlines for each can be listed. What sources of funding may be available to help accomplish these goals? Who might be interviewed to find out how they accomplished their professional goals? What support groups or networks can be used to help ensure the plan will not be abandoned?

\section{Table 9}

Goals, Resources, Obstacles, Solutions, and Deadlines

\begin{tabular}{|c|l|l|l|l|}
\hline $\begin{array}{c}\text { Long-Term } \\
\text { Professional } \\
\text { Goal }\end{array}$ & \multicolumn{1}{|c|}{ Resources } & Obstacles & Solutions & Deadlines \\
\hline $\begin{array}{c}\text { PhD in Applied } \\
\text { Linguistics }\end{array}$ & PhD colleagues & No funding & $\begin{array}{l}\text { Loans? } \\
\text { Scholarships? }\end{array}$ & 2021 \\
\hline $\begin{array}{c}\text { Short-Term } \\
\text { Professional } \\
\text { Goals }\end{array}$ & Resources & Obstacles & Solutions & Deadlines \\
\hline $\begin{array}{c}\text { 1. Identify } \\
\text { programs }\end{array}$ & Online search & $\begin{array}{l}\text { Too many to } \\
\text { sort through }\end{array}$ & $\begin{array}{l}\text { Keep notes of } \\
\text { best options }\end{array}$ & 2013 spring \\
\hline $\begin{array}{c}\text { 2. Create } \\
\text { finance plan }\end{array}$ & $\begin{array}{l}\text { Mentor or } \\
\text { university staff }\end{array}$ & $\begin{array}{l}\text { Not aware of } \\
\text { options }\end{array}$ & $\begin{array}{l}\text { Email } \\
\text { universities }\end{array}$ & 2013 fall \\
\hline $\begin{array}{l}\text { 3. Complete } \\
\text { application }\end{array}$ & Colleagues & $\begin{array}{l}\text { Writing a good } \\
\text { essay }\end{array}$ & $\begin{array}{l}\text { Ask colleagues } \\
\text { to help edit }\end{array}$ & 2014 spring \\
\hline & & & & \\
\hline
\end{tabular}


A final and important overarching consideration is whether the plan allows one to maintain and sustain a balanced social and family life. Cohen (2003) discusses the importance of nurturing relationships with friends and family when planning career goals.

\section{Conclusion}

This paper has argued for the importance of professional development, discussed several reasons why teachers might make it a priority, and provided numerous examples of how it can be accomplished in spite of limited resources. It has outlined possible steps for language educators to take to create a professional development plan based on a reflective approach on one's practice, specific context, and personal goals.

I will conclude with a personal anecdote. After one of my very first TESOL presentations, entitled Ten Communicative Projects to Energize Listening / Speaking Classes, a woman rushed up to me with a pen and paper in hand and said, "I am so sorry, but I came in late. What was the name of your book again?" I was stunned by her question, because she obviously thought I had written a book. But I started thinking, well, why not? If she thinks I could write a book, then maybe I really can. On the plane home, I made a long list of possible titles for "my book," and some years later, it really happened. Those ten activities became ten chapters, and Cambridge published that book, which was on the market for over a decade. I don't know who that woman was, but she launched me on my professional journey. Sometimes all we need is someone to believe in us, someone who plants a seed of possibility that takes root and grows. So I put it to you: What's the name of your book?

\section{Author Note}

Mary Shepard Wong, Department of Global Studies, Sociology, and TESOL, Azusa Pacific University, California, U.S.A.

This article was based on a presentation given at the 4th Annual CamTESOL Conference, Phnom Penh, Cambodia in 2008 entitled: Diagnosing your strengths and weakness: Planning your professional development. It also draws from the presentation given at CATESOL $40^{\text {th }}$ Annual State Conference, Pasadena, CA in 2009, Planning your career as a language educator.

Correspondence concerning this article should be addressed to Mary Shepard Wong, Department of Global Studies, Sociology, and TESOL, Azusa Pacific University, 901 E. Alosta Ave., Azusa, California, 91702-7000 U.S.A. E-mail: mwong@apu.edu. 


\section{References}

Algren, M. (2003). Developing through e-mail discussion lists. In J. Egbert (Ed.), Becoming contributing professionals (pp. 89-95). Alexandria, VA: TESOL.

Andrade, M. S. (2003). In the limelight: Presenting to your peers. In J. Egbert (Ed.), Becoming contributing professionals (pp. 15-23). Alexandria, VA: TESOL.

Averill, J. E. (2003). Writing for grant dollar\$. In P. Byrd \& G. Nelson (Eds.), Sustaining professionalism (pp. 35-42). Alexandria, VA: TESOL.

Bailey, K. M. (2004). Promoting our own professional development through reflective teaching journals. The New Zealand Language Teacher, 30, 10-16.

Bailey, K. M. (2006). Language teacher supervision: A case-based approach. New York, NY: Cambridge University Press.

Bailey, K. M., Curtis, A., \& Nunan, D. (2001). Pursuing professional development: The self as source. New York, NY: Heinle \& Heinle.

Bailey, K. M., \& Nunan, D. (Eds.). (1996). Voices from the language classroom. New York, NY: Cambridge University Press.

Bain, K. (2004). What the best college teachers do. Cambridge, MA: Harvard University Press.

Borg, S. (2003a). Pulp fiction? The research journal and professional development. In T. Murphey (Ed.), Extending professional contributions (pp. 39-46). Alexandria, VA: TESOL.

Borg, S. (2003b). Teacher cognition in language teaching: A review of research on what language teachers think, know, believe, and do. Language Teaching, 36(2), 81-109. http://dx.doi.org/10.1017/S0261444803001903

Boucher-Yip, E. F. (2003). Crossing borders: Volunteering overseas. In J. Egbert (Ed.), Becoming contributing professionals (pp. 9-14). Alexandria, VA: TESOL.

Braine, G. (2003). Starting a TESOL caucus for nonnative speakers of English: The politics of professional development. In P. Byrd \& G. Nelson (Eds.), Sustaining professionalism (pp. 113-120). Alexandria, VA: TESOL.

Burns, A. (1999). Collaborative action research for English language teachers. New York, NY: Cambridge University Press.

Burns, A. (2010). Doing action research in English language teaching: A guide for practitioners. New York, NY: Routledge.

Canagarajah, S. (2006). In this issue. TESOL Quarterly, 40(1), 5-6.

Carbery, S., \& Croker, R. (2003). Thais that bind: Becoming a teacher educator through international volunteering. In T. Murphey (Ed.), Extending professional contributions (pp. 87-95). Alexandria, VA: TESOL.

Chao, C.-c. (2003). Professional development on cloud nine: Online conferencing. In J. Egbert (Ed.), Becoming contributing professionals (pp. 107-115). Alexandria, VA: TESOL.

Christison, M., \& Murray, D. (2009). Leadership in English language education: Theoretical foundations and practical skills for changing times. New York, NY: Routledge.

Cohen, A. (2003). Becoming "Scholar of the College." In P. Byrd \& G. Nelson (Eds.), Sustaining professionalism (pp. 9-17). Alexandria, VA: TESOL.

Conrad, S. (2003). Moving into the unknown: When leaving a secure position sustains your professionalism. In P. Byrd \& G. Nelson (Eds.), Sustaining professionalism (pp. 97-103). Alexandria, VA: TESOL.

Curtis, A. (2006). In service: Weighing the why and why nots of professional development. Essential Teacher, 3(1), 14-15.

Curtis, A. (2008). The seven principles of professional development: From A to G. In C. Coombe, M. L. McCloskey, L. Stephenson, \& N. Anderson (Eds.), Leadership in English language teaching and learning (pp. 117-127). Ann Arbor, MI: University of Michigan Press. 
Deacon, B. (2003). Priceless peer-mentor observation. In J. Egbert (Ed.), Becoming contributing professionals (pp. 81-88). Alexandria, VA: TESOL.

Diaz-Maggioli, G. H. (2003, August). Professional development for language teachers. CAL Digest. (EDO-FI-03-03). (retrieved from: http://www.cal.org/resources/digest/ digest_pdfs/0303diaz.pdf

Edge, J. (Ed.). (2001). Action research. Alexandria, VA: TESOL.

Eisterhold, J. (2003). Making new friends: Becoming involved in a TESOL organization. In J. Egbert (Ed.), Becoming contributing professionals (pp. 1-7). Alexandria, VA: TESOL.

Fowle, C., \& Durham, J. (2001, April/May). Stories of professional development in Thailand and Laos. IATEFL, 160, 12-13.

Freeman, D. (1998). Doing teacher research: From inquiry to understanding. New York, NY: Heinle \& Heinle.

Gordon, T. (2003). Learning from our students: Using students to develop curricula. In J. Egbert (Ed.), Becoming contributing professionals (pp. 59-66). Alexandria, VA: TESOL.

Gorsuch, G., \& Beglar, D. (2003). Fostering graduate school teacher development through peer interviewing. In T. Murphey (Ed.), Extending professional contributions (pp. 29-37). Alexandria, VA: TESOL.

Grant, L. (2003). Small corrections: Becoming a textbook writer. In P. Byrd \& G. Nelson (Eds.), Sustaining professionalism (pp. 51-57). Alexandria, VA: TESOL.

Graves, K. (2000). Designing language courses: A guide for teachers. Boston, MA: Heinle \& Heinle.

Graves, K. (Ed.). (1996). Teachers as course developers. New York, NY: Cambridge University Press.

Green, C. (2003). Net gains. In T. Murphey (Ed.), Extending professional contributions (pp. 5765). Alexandria, VA: TESOL.

Johnson, K., \& Golombek, P. (Eds.). (2002). Teachers' narrative inquiry as professional development. New York, NY: Cambridge University Press.

Kupetz, M. (2003). Having dessert first: Writing book reviews. In J. Egbert (Ed.), Becoming contributing professionals (pp. 25-31). Alexandria, VA: TESOL.

Lange, D. L. (1990). A blueprint for a teacher development program. In J. C. Richards and D. Nunan (Eds.), Second language teacher education (pp. 245-268). New York, NY: Cambridge University Press.

Mattix, M. (2003). Sounding your singing voice: Publishing in forum sections. In J. Egbert (Ed.), Becoming contributing professionals (pp. 33-39). Alexandria, VA: TESOL.

McKay, S. (2006). Researching second language classrooms. Mahwah, NJ: Lawrence Erlbaum.

Miller, P. L. (2003). How would PhD feel after your name? In T. Murphey (Ed.), Extending professional contributions (pp. 47-55). Alexandria, VA: TESOL.

Murphey, T., Connolly, M., Churchill, E., McLaughlin, J., Schwartz, S. L., \& Krajka, J. (2003). Creating publishing communities. In T. Murphey (Ed.), Extending professional contributions (pp. 105-118). Alexandria, VA: TESOL.

Murphy, J. M. (2003). The roller coaster ride of editing a book. In P. Byrd \& G. Nelson (Eds.), Sustaining professionalism (pp. 43-50). Alexandria, VA: TESOL.

Nunan, D. (1999). President's message: October/November 1999. TESOL Matters, 9(5), 1.

Palmer, P. (2007). The courage to teach: Exploring the inner landscape of a teacher's life. New York, NY: Jossey-Bass.

Paulus, T. M. (2003). The web of professional development. In J. Egbert (Ed.), Becoming contributing professionals (pp. 97-106). Alexandria, VA: TESOL. 
Pawan, F., \& Jacobson, A. (2003). Growing with the flow: Sustaining professionalism through online instruction of language teachers. In T. Murphey (Ed.), Extending professional contributions (pp. 67-78). Alexandria, VA: TESOL.

Richards, J. C. (1998). Beyond training. New York, NY: Cambridge University Press.

Richards, J. C. (2001). Curriculum development in language teaching. New York, NY: Cambridge University Press.

Richards, J. C., \& Farrell, T. S. C. (2005). Professional development for language teachers: Strategies for teacher learning. New York, NY: Cambridge University Press.

Richards, J. C., \& Lockhart, C. (1996). Reflective teaching in second language classrooms. New York, NY: Cambridge University Press.

Roessingh, H., \& Johnson, C. (2005). Online teaching and learning in TESL professional development. The Quarterly Review of Distance Education, 6(2), 107-115.

Rubin, J., \& Thompson, I. (1994). How to be a more successful language learner. Boston, MA: Heinle and Heinle.

Sato, K. (2003). Starting a local teacher study group. In T. Murphey (Ed.), Extending professional contributions (pp. 97-104). Alexandria, VA: TESOL.

Sauro, S. (2003). In your students' shoes: Learning a foreign language as professional development. In J. Egbert (Ed.), Becoming contributing professionals (pp. 67-73). Alexandria, VA: TESOL.

Seymour, S. (2003). Sabbatical projects can make a difference: A tale of curriculum revision. In P. Byrd \& G. Nelson (Eds.), Sustaining professionalism (pp. 89-96). Alexandria, VA: TESOL.

Smith, R. (2003). A far cry from the classroom: Becoming an administrator. In P. Byrd \& G. Nelson (Eds.), Sustaining professionalism (pp. 65-72). Alexandria, VA: TESOL.

Stapa, S. H. (2003). Going for the gold: Managing an academic department. In P. Byrd \& G. Nelson (Eds.), Sustaining professionalism (pp. 59-64). Alexandria, VA: TESOL.

Stewart, T., \& Lokon, E. (2003). Professional development through student and teacher reaction journals. In T. Murphey (Ed.), Extending professional contributions (pp. 19-27). Alexandria, VA: TESOL.

Tanner, R. (2003). Outside in, inside out: Creating a teaching portfolio. In P. Byrd \& G. Nelson (Eds.), Sustaining professionalism (pp. 19-25). Alexandria, VA: TESOL.

TIRF (The International Research Foundation for English Language Education). (2011). Professional Development of Language Teachers: Selected References (last updated 31 May 2011). Retrieved from http://www.tirfonline.org/wp-content/uploads/2011/05/ ProfessionalDevelopmentOfLanguageTeachers_SelectedReferences_31May2011.doc

Tjandrawidjaja, J. R. (2003). Turning survival notes into textbook manuals: Saving and sharing our work. In J. Egbert (Ed.), Becoming contributing professionals (pp. 41-47). Alexandria, VA: TESOL.

Wajnryb, R. (1992). Classroom observation tasks. New York, NY: Cambridge University Press.

Waldschmidt, E. D., Dantas-Whitney, M., \& Healey, D. (2005). Communities of support: A professional development project for teachers of English language learners. In T. Murphey \& K. Sato (Eds.), Communities of supportive professionals (pp. 77-89). Alexandria, VA: TESOL. 